Czerwińska Pawluk Iwona, Mic Lukasz. Mothers' knowledge about urinary tract infections in children and their prevention. Pedagogy and Psychology of Sport. 2020;6(2):40-50. elSSN 2450-6605. DOI http://dx.doi.org/10.12775/PPS.2020.06.02.004 https://apcz.umk.pl/czasopisma/index.php/PPS/article/view/PPS.2020.06.02.004

https://zenodo.org/record/3766548

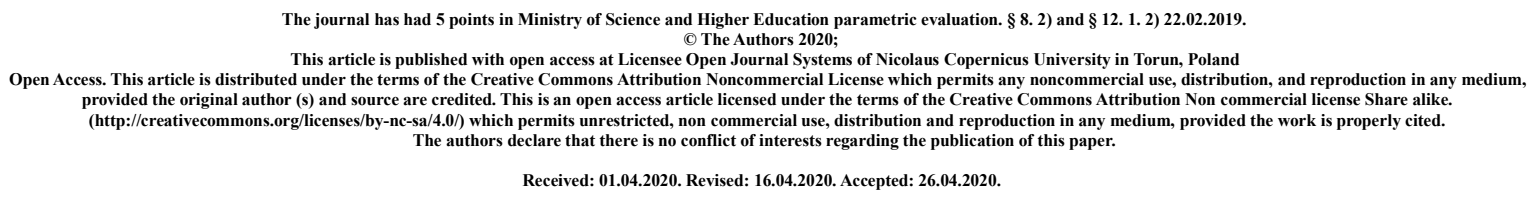

\title{
Mothers' knowledge about urinary tract infections in children and their prevention
}

\author{
Iwona Czerwińska Pawluk, Lukasz Mic
}

dr n. med. Iwona Czerwińska Pawluk - Radomska Szkoła Wyższa w Radomiu, Uniwersytecki Szpital Dziecięcy, Lublin.

Łukasz Mic - absolwent Radomskiej Szkoły Wyższej w Radomiu i WSBiP w Ostrowcu Świętokrzyskim, Wojewódzkie Pogotowie Ratunkowe, ul. Spadochroniarzy 8 Lublin, Szpital Neuropsychiatryczny SPZOZ, ul.Abramowicka 2 Lublin.

\begin{abstract}
Urinary tract infections (UTIs) are a serious medical problem. The disease affects a significant percentage of children, including newborns, infants, older children and adolescents. Numerous factors influence the course of UTI and the manifestation of clinical symptoms. UTIs that are diagnosed too late, untreated or poorly treated are the cause of many complications that can pose a serious threat to the health and even life of a child. In the prevention of UTI, in their diagnosis and therapy, an important role is played by nursing staff, who have an obligation to educate child carers on the subject of risk factors, the importance of check-ups in early diagnosis of infections, and rules in force during therapy. It is not without significance to learn skills related to the care of the child's intimate areas, as well as the principles relevant for the prevention of relapses.
\end{abstract}

Key words: urinary tract infections; knowledge, prevention.

\section{Streszczenie}

Zakażenia układu moczowego (ZUM) stanowią poważny problem medyczny. Choroba dotyczy znacznego odsetka dzieci, w tym: noworodków, niemowląt, dzieci starszych a także młodzieży. Na przebieg ZUM i manifestację objawów klinicznych wpływ mają liczne czynniki. ZUM zbyt późno rozpoznane, nieleczone lub źle leczone są przyczyną wielu powikłań mogących stanowić poważne zagrożenie dla zdrowia, a nawet życia dziecka. W profilaktyce ZUM, w ich diagnostyce i terapii ważną rolę odgrywa personel pielęgniarski, na którym ciąży obowiązek edukacji opiekunów dziecka na temat czynników ryzyka, znaczenia badań kontrolnych we wczesnej diagnostyce zakażeń, zasad obowiązujących w czasie terapii. Nie bez znaczenia jest nauka umiejętności związanych $\mathrm{z}$ pielęgnacją okolic intymnych dziecka, a także zasad istotnych w profilaktyce nawrotów. 
Słowa kluczowe: zakażenia układu moczowego; wiedza, profilaktyka.

Zakażenia układu moczowego (ZUM) u dzieci stanowią problem współczesnej pediatrii. Częstość występowania ZUM w populacji dziecięcej wynosi 2-8\%. Szczyt zapadalności ma miejsce między 2 a 6 r. ż., a ryzyko zakażenia jest 10-30 razy większe u dziewcząt w porównaniu z chłopcami. Do okresu dojrzewania co 10 - te dziecko co najmniej raz przechodzi ZUM. U młodzieży przyczyną ZUM jest wczesna i większa aktywność seksualna. Ryzyko nawrotu ZUM w ciągu pierwszych 6-12 miesięcy po zakażeniu wynosi 12$30 \%$ [2]. U większości dzieci ZUM ma podłoże bakteryjne. Przyczyną ZUM są także inne patogeny, w tym: wirusy, pasożyty, grzyby, bakterie atypowe [2]. U około 30\% chłopców za przyczynę ZUM odpowiedzialne są Proteus species często kolonizujące napletek. U noworodków najczęstszą przyczyną ZUM są bakterie Gram-dodatnie i Klebsiella species. Zakażenia grzybicze występują głównie u dzieci z upośledzoną odpornością. Klinicznie zakażenia grzybicze występują jako: zapalenie cewki moczowej, zapalenie pęcherza moczowego oraz śródmiąższowe zapalenie nerek [2]. Większe ryzyko ZUM jest większe u dzieci, u których występują przeszkody w odpływie moczu (wady układu moczowego, kamica, zaburzenia neurogenne czynności pęcherza) [3]. Na rozwój ZUM mają wpływ też takie czynniki, jak: rzadkie i nieefektywne mikcje, zastój moczu, zbyt wolna perystaltyka moczowodów, zaparcia, owsica, cewnikowanie pęcherza moczowego w celach diagnostycznych i terapeutycznych. Drogą krwiopochodną ZUM szerzy się jako powikłanie zakażenia ogólnego organizmu $[4,5]$.

ZUM definiuje się jako następstwo obecności drobnoustrojów powyżej zwieracza pęcherza moczowego [4]. Biorąc pod uwagę lokalizację zmian wyróżnia się zakażenia dolnego odcinka układu moczowego (zapalenie pęcherza moczowego, zapalenie cewki moczowej, zapalenie gruczołu krokowego) i górnego odcinka układu moczowego (ostre odmiedniczkowe zapalenie nerek) [5]. Biorąc zaś pod uwagę przebieg kliniczny choroby wyróżnia się zakażenia typowe (wywołane przez E. Coli, łatwo poddają się leczeniu i nie towarzyszą im zaburzenia wydalania moczu i upośledzenie czynności nerek), oraz zakażenia atypowe, które charakteryzują się: odchyleniami od normy w badaniu przedmiotowym, ciężkim przebiegiem klinicznym choroby, podwyższonym stężeniem kreatyniny w surowicy krwi, zaburzeniami w wydalaniu moczu, brakiem poprawy klinicznej po antybiotykoterapii ukierunkowanej na najczęstsze uropatogeny [6]. 
Tabela I. Postacie kliniczne ZUM i ich objawy.

\begin{tabular}{|l|l|}
\hline Postać kliniczna ZUM & Objawy \\
\hline Bezobjawowy bakteriomocz & Znamienny bakteriomocz jako izolowany objaw \\
\hline Bezobjawowe ZUM & Znamienny ropomocz i bakteriomocz \\
\hline $\begin{array}{l}\text { Zakażenia dolnego odcinka } \\
\text { układu moczowego }\end{array}$ & $\begin{array}{l}\text { Bakteriomocz, częstomocz, ropomocz, krwiomocz, } \\
\text { niepokój, ból przy oddawaniu moczu }\end{array}$ \\
\hline $\begin{array}{l}\text { Ostre odmiedniczkowe } \\
\text { zapalenie nerek }\end{array}$ & $\begin{array}{l}\text { Bakteriomocz, podwyższone OB., wzrost stężenia } \\
\text { CRP, leukocytoza, ropomocz, ogniska zmniejszonego } \\
\text { wychwytu znacznika w renoscyntygrafii (DMSA) } \\
\text { Dzieci starsze: gorączka 38, nudności, wymioty, } \\
\text { bóle brzucha i w okolicy lędźwiowej }\end{array}$ \\
\hline $\begin{array}{l}\text { Przewlekłe odmiedniczkowe } \\
\text { zapalenie nerek }\end{array}$ & $\begin{array}{l}\text { Okresowy bakteriomocz i ropomocz, upośledzenie } \\
\text { czynności nerek, nadciśnienie spowodowane } \\
\text { odpływami wstecznymi, kamica, wapnica nerek, } \\
\text { utrudniony odpływ moczu, powtarzające się epizody } \\
\text { ostrego odmiedniczkowego zapalenia nerek, } \\
\text { neurogennych zaburzeń czynności pęcherza }\end{array}$ \\
\hline
\end{tabular}

Źródło: Wardyna K., Życiński K. Zakażenia układu moczowego. Wydawnictwo Czelej, Lublin 2006.

Na przebieg kliniczny ZUM wpływ mają różne czynniki, w tym: wiek dziecka, jego stan ogólny, lokalizacja i ciężkość zmian zapalnych, współistnienie wad układu moczowego i innych chorób przewlekłych [7]. U dzieci najmłodszych objawy choroby są mało specyficzne: ból brzucha. ogólne rozdrażnienie, wymioty, niechęć do jedzenia, gorączka, objawy dyzuryczne (ból lub pieczenie podczas oddawania moczu, częste parcie na pęcherz moczowy, dyskomfort lub ból w podbrzuszu, oddawanie moczu małymi porcjami), a nawet zahamowanie przyrostów wagi ciała [1].

Tabela II. Przebieg kliniczny ZUM w zależności od wieku dziecka.

\begin{tabular}{|c|c|c|c|}
\hline $\begin{array}{l}\text { Wiek } \\
\text { dziecka }\end{array}$ & Objawy wiodące & Objawy dodatkowe & Uwagi \\
\hline$<3 \mathrm{~m} \cdot \dot{\mathrm{z}}$ & $\begin{array}{l}\text { Gorączka, wymioty, } \\
\text { biegunka, niechęć do } \\
\text { jedzenia, niepokój, } \\
\text { przedłużająca } \\
\text { żółtaczka }\end{array}$ & $\begin{array}{lr}\text { Ból } & \text { brzucha, } \\
\text { krwiomocz, } & \text { zmiana } \\
\text { właściwości } & \text { moczu } \\
\text { (barwa, } & \text { zapach, } \\
\text { przejrzystość) } & \\
\end{array}$ & $\begin{array}{l}\text { Najcięższy przebieg } \\
\text { ZUM, możliwość } \\
\text { uogólnionej infekcji, } \\
\text { częściej u chłopców }\end{array}$ \\
\hline $3 \mathrm{~m} \cdot \dot{\mathrm{z}}-3 \mathrm{r} \cdot \dot{\mathrm{z}}$ & $\begin{array}{lr}\text { Gorączka, } & \text { biegunka, } \\
\text { wymioty, } & \text { bóle } \\
\text { brzucha } & \text {,zmiana } \\
\text { właściwości } & \text { moczu } \\
\text { (barwa, } & \text { zapach, } \\
\text { przejrzystość), niechęć } \\
\text { do jedzenia }\end{array}$ & $\begin{array}{l}\text { Niepokój, senność, } \\
\text { krwiomocz, } \\
\text { zahamowanie } \\
\text { wzrostu, nadmierna } \\
\text { drażliwość }\end{array}$ & \\
\hline$>3$ r.ż & $\begin{array}{lr}\text { Objawy dyzuryczne, } \\
\text { ból w okolicy } \\
\text { lędźwiowej, gorączka, } \\
\text { dodatni } \\
\text { Goldflama }\end{array}$ & $\begin{array}{lr}\text { Krwiomocz, zmiana } \\
\text { właściwości moczu } \\
\text { (barwa, przejrzystość, } \\
\text { zapach), } \\
\text { samopoczucie }\end{array}$ & $\begin{array}{l}\text { Częściej u } \\
\text { dziewczynek }\end{array}$ \\
\hline
\end{tabular}

Źródło: Grenda R., Ziółkowska H. (red.). Choroby układu moczowego. W: Kawalec W., Grenda R., Ziółkowska H.(red.). Pediatria. Tom I. Wydawnictwo Lekarskie PZWL, Warszawa 2013. ISBN 978-83-200-4630-4. 
Podstawą diagnostyki ZUM jest prawidłowo przeprowadzony wywiad z opiekunem dziecka, w przypadku dziecka starszego także $\mathrm{z}$ dzieckiem. Wywiad jest źródłem wielu informacji ułatwiających ustalenie czynnika etiologicznego, przebiegu choroby, obciążenia rodzinnego chorobami ze strony układu moczowego, poziomu wiedzy rodziców/ opiekunów dziecka na temat ZUM, możliwości ich profilaktyki. Istotną rolę odgrywa też badanie fizykalne, podczas którego należy dokonać oceny wszystkich narządów i układów, ze zwróceniem szczególnej uwagi na układ moczowy i okolicę cewki moczowej. Nie bez znaczenia są badania laboratoryjne, w tym badanie ogólne i badanie bakteriologiczne moczu. Mocz na posiew powinien być pobrany przed rozpoczęciem leczenia [9]. Za normę leukocyturii przyjmuje się obecność do 10 leukocytów w polu widzenia w moczu odwirowanym oraz do $5 \mathrm{w}$ moczu nieodwirowanym. Obecność $100000(105 / \mathrm{ml})$ lub więcej bakterii w $1 \mathrm{ml}$ moczu oznacza znamienną bakteriurię [2]. U dzieci $\mathrm{z}$ nawracającymi ZUM badanie moczu ogólne i bakteriologiczne powinno być wykonywane co miesiąc rutynowo i każdorazowo w przypadku niepokojących objawów, a także gorączki nieznanego pochodzenia [2]. Nie bez znaczenia są także badania laboratoryjne krwi. Podwyższone wartości CRP, prokalcytoniny, leukocytoza wskazują na ostry proces zapalny i są pomocne w odróżnieniu zapalenia tkanki śródmiąższowej nerek od zapalenia pęcherza moczowego. U dzieci w stanie ciężkim zalecany jest posiew krwi [11]. W przypadku podejrzenia lub rozpoznania ZUM wykonuje się badania obrazowe, mające na celu rozpoznanie lub wykluczenie wady wrodzonej, w tym także odpływu pęcherzowo-moczowodowego, kamicy moczowej oraz uwidocznienie innych patologicznych zmian w układzie moczowym [3]. U dzieci z nawracającymi ZUM zalecane jest badanie urodynamiczne i wykonanie testów czynnościowych $[2,12]$.

Leczenie zakażeń układu moczowego zależy od wieku pacjenta, jego stanu klinicznego, wrażliwości uropatogenów i chorób współistniejących i powinno być rozpoczęte bezpośrednio po rozpoznaniu choroby [8]. Celem leczenia ZUM jest wyjałowienie dróg moczowych, zapewnienie fizjologicznych warunków do odpływu moczu, zminimalizowanie ryzyka odległych następstw zakażenia. W terapii ZUM obowiązuje zasada „im młodsze dziecko i cięższa postać choroby tym terapia intensywniejsza" [2]. Według Polskiego Towarzystwa Nefrologii Dziecięcej (PTNFD) wiek dziecka poniżej 3 miesiąca życia jest bezwzględnym wskazaniem do leczenia szpitalnego. Wskazaniem do hospitalizacji są także powikłane lub atypowe ZUM, podejrzenie zakażenia uogólnionego, zły stan ogólny, gorączka utrzymująca się $>3$ dni pomimo antybiotykoterapii oraz brak współpracy z opiekunami dziecka [13]. W opiece nad dzieckiem hospitalizowanym $\mathrm{z}$ powodu ZUM obowiązkiem personelu pielęgniarskiego jest wykonywanie procedur o charakterze diagnostycznym jak i terapeutycznym. Ważnym elementem jest rozpoznawanie problemów opiekuńczopielęgnacyjnych u dziecka/ opiekunów dziecka, planowanie opieki i jej realizacja, a także planowanie i prowadzenie działań edukacyjnych wobec dziecka i/lub jego opiekunów [3, 14]. W ramach edukacji opiekunowie dziecka muszą posiąść wiedzę na temat choroby, czynników ryzyka, powikłań choroby i profilaktyki nawrotów. Konieczne jest też nabycie umiejętności niezbędnych w procesie: identyfikowania i eliminowania czynników ryzyka ZUM, zmniejszenia ekspozycji ujścia zewnętrznego cewki na zanieczyszczenia (profilaktyka stanów zapalnych pochwy i krocza, przestrzeganie nawyków higienicznych podczas kąpieli, korzystania $\mathrm{z}$ toalety, codzienna zmiana bielizny osobistej), eliminacji uropatogenów $\mathrm{z}$ pęcherza moczowego (całkowite opróżnianie pęcherza, podaż odpowiedniej ilości płynów do picia, regulacja wypróżnień, nie przetrzymywanie moczu), rozpoznawania objawów i wczesnego reagowania, najpóźniej do 48 godzin od wystąpienia pierwszych objawów ZUM, pomiarów ciśnienia tętniczego krwi $[15,17]$.

Profilaktyczna farmakoterapia ZUM u dzieci nie jest rekomendowana. Nie ma ona wpływu na zmniejszenie częstości nawrotów ZUM, a nawet może być przyczyną wzrostu oporności bakterii i działań ubocznych. Profilaktyka ZUM polegająca na podawaniu furaginy lub trimetoprimu $\mathrm{w}$ pojedynczej dawce na noc wskazana jest $\mathrm{u}$ dzieci $\mathrm{z}$ wadami układu moczowo-płciowego i dzieci z pęcherzem neurogennym. W ramach profilaktyki nawrotów 
zalecane jest zakwaszenie moczu poprzez podaż witaminy C czy też żurawiny [16]. Owoce żurawiny zawierają substancję, która hamuje adhezję E.coli do nabłonka dróg moczowych [16]. Dzieci poniżej 2 r. ż po przebytym epizodzie ZUM, oraz niezależnie od wieku z nawrotowymi ZUM czy czynnikami ryzyka nawrotu muszą być objęte opieką lekarza nefrologa [17]. Konieczne jest leczenie zaparć i zaburzeń czynnościowych pęcherza, dbanie o regularne wypróżnienia (dieta i aktywność fizyczna). Liczne badania dowodzą, że u dzieci karmionych piersią zmniejsza się częstość ZUM. Efekt ochronny karmienia naturalnego może wynikać z modelującego wpływu pokarmu na florę jelitową jak i przekazywania biernej odporności za pośrednictwem sekrecyjnej IgA. Bardzo ważne jest poinformowanie opiekunów dziecka o konieczności wykonywania badań kontrolnych i następstwach nie leczonych lub źle leczonych ZUM. Rodziców/ opiekunów dzieci należy uwrażliwić na objawy, które powinny budzić podejrzenie nawrotu choroby [7]. W profilaktyce ZUM i ich nawrotów konieczne jest przestrzeganie higieny osobistej. Okolicę zewnętrznych narządów płciowych należy myć często ciepłą wodą, wskazana jest kąpiel pod prysznicem. Przeciwwskazane jest stosowanie dezodorantów na okolice intymne [5]. Często zachodzi konieczność zmiany stylu życia na sprzyjający zdrowiu.

Ważną rolę w opiece nad dzieckiem z ZUM i w profilaktyce nawrotów odgrywają opiekunowie dziecka, którzy nierzadko zmieniają styl życia dziecka, modyfikują środowisko w którym dziecko przebywa, rozpoznają objawy wskazujące na ZUM, pobierają mocz do badań laboratoryjnych i wdrażają terapie wcześniej uzgodnione z lekarzem.

Ze względu na wagę problemu zostały przeprowadzona badania, których celem była ocena wiedzy matek na temat ZUM u dzieci i ich profilaktyki. Badania przeprowadzono w Przychodni Rodzinne Centrum Medyczne w Lublinie, przy ulicy Woronieckiego, w okresie od grudnia 2018 roku do marca 2019 r. Badaniem objęto 101 matek, sprawujących opiekę nad dzieckiem z przebytym lub aktualnie leczonym ZUM.

Celem przeprowadzenia badań wykorzystana została metoda jaką był sondaż diagnostyczny, technika ankiety i narzędzie badawcze jakim był kwestionariusz ankiety.

$\mathrm{Z}$ analizy danych socjodemograficznych badanych wynika, że największy odsetek stanowiły matki w wieku 31-39 lat -47 (46,5\%). W badaniu wzięło udział 29 matek $(28,75 \%) \mathrm{w}$ wieku $\leq 30$ lat i 25 matek $(24,8 \%) \mathrm{w}$ wieku $\geq 40$ lat. Najwięcej ankietowanych pochodziło z miasta pow. 100 tys. mieszkańców (52,5\%), 28\% respondentek pochodziło ze wsi, pozostałe to mieszkanki miast do 100 tys. mieszkańców. Najliczniejszą grupę badanych stanowiły matki posiadające wyższe i średnie wykształcenie (po 44,6 \%). Matki z wykształceniem zasadniczym stanowiły 7\% ogółu badanych, a $\mathrm{z}$ wykształceniem podstawowym 4\%. W badaniu wzięło udział 60,4 \% matek wykonujących zawody niemedyczne i $22,0 \%$ wykonujących zawody medyczne. Pozostałe $18 \%$ badanych matek to osoby niepracujące. Badanym zadano pytanie na temat ich sytuacji materialnej. Większość badanych matek określiło swoją sytuację materialną jako dobrą - 60,4\%, 14\% ankietowanych określiło swoją sytuację materialną jako bardzo dobrą, 24,5\% \% jako przeciętną, a $1,0 \%$ jako złą.

$\mathrm{Na}$ rozwój i przebieg kliniczny ZUM u dzieci wpływ mają różne czynniki, w tym patogeny, które przedostały się do układu moczowego. Badane wykazały się wiedzą na temat patogenów będących przyczyną ZUM. Zdaniem 73,3 \% ankietowanych najczęściej przyczyną ZUM są bakterie. Wirusy jako główna przyczyna ZUM zostały wskazane przez $18 \%$ badanych, grzyby przez $14 \%$ i pasożyty przez $2 \%$ badanych matek. W literaturze opisane są różne czynniki zwiększające ryzyko rozwoju ZUM u dzieci. Zdaniem ankietowanych matek ZUM częściej występują u dziewczynek - 57,4\%. Tylko 4,9\% badanych matek była zdania, że ZUM częściej występuje u chłopców. Wg 37,7\% badanych płeć nie ma wpływu na częstość występowania ZUM. 82,5\% badanych matek za czynnik ryzyka ZUM wskazało ogólną infekcję, 42\% wskazało na nieprzestrzeganie higieny osobistej. Matki, których dzieci często były leczone z powodu ZUM częściej wskazywały na takie czynniki ryzyka, jak: zaparcia i owsica $(p<0,05)$. Liczba posiadanych dzieci przez badane matki nie pozostawała $\mathrm{w}$ związku z poziomem wiedzy badanych na temat czynników 
ryzyka. W badaniu nie stwierdzono też istotnych statystycznie zależności między wiedzą matek na temat czynników ryzyka ZUM, a częstością występowania ZUM i liczbą dzieci.

ZUM manifestuje się różnymi objawami, co jest zależne od wieku dziecka, lokalizacji zmian, chorób współistniejących. Badane matki zostały poproszone o wskazanie objawów sugerujących ZUM u dziecka. Z przeprowadzonej analizy wynika, że ponad połowa ankietowanych za główny objaw ZUM wskazała bolesne parcie na mocz $(59,4 \%)$ oraz pieczenie cewki moczowej podczas oddawania moczu (53,5\%). Inne objawy ZUM, które były rzadziej wskazywane przez badane matki, to: częste oddawanie moczu w małych ilościach (45,5\%), bóle brzucha (31,7\%) i zmieniony zapach moczu (30,7\%). Najrzadziej wskazywane przez badane matki objawy ZUM, to: gorączka, niechęć do ssania, płacz dziecka $(17,8 \%)$ oraz bóle w okolicy nerek $(16,8 \%)$. 5\% badanych matek przyznało się do nieznajomości objawów ZUM u dzieci. W badaniu potwierdzono istotne statystycznie zależności pomiędzy częstością występowania ZUM u dziecka a wiedzą matek na temat objawów ZUM. Matki, u których dzieci ZUM występowało 2-3 razy w ciągu roku miały wyższy poziom wiedzy na temat objawów ZUM.

W ramach diagnostyki ZUM wykonywane są różne badania. Przeprowadzone badania wskazują na brak wiedzy matek na temat diagnostyki ZUM. Zdaniem większości badanych podstawą diagnostyki ZUM jest badanie ogólne moczu (76,2\%). Na badanie bakteriologiczne moczu wskazało tylko 52,5\% badanych matek. Pozostałe badania wskazywane były rzadko: USG jamy brzusznej (28,7\%), cystografia i urografia (7,9\%), tomografia komputerowa (3\%). $6,9 \%$ badanych matek w ogóle nie posiadało wiedzy na diagnostyki ZUM u dzieci. Matki, których dzieci częściej chorowały wykazały się większą wiedzą w tym zakresie niż pozostałe $(\mathrm{p}<0,05)$.

Podstawowym badaniem istotnym w diagnostyce ZUM jest badanie ogólne i badanie bakteriologiczne moczu. Aby wynik badania był wiarygodny konieczne jest przestrzeganie zasad podczas pobierania moczu, w czasie przechowywania moczu i podczas transportu do laboratorium. Największą wartość diagnostyczną ma pierwsza porcja moczu pobranego po nocy [18]. Przed pobraniem moczu dziecko należy dokładnie podmyć wodą z mydłem, a następnie okolicę ujścia zewnętrznego cewki delikatnie osuszyć jednorazowym ręcznikiem. Próbkę moczu należy pobrać ze środkowego strumienia [4]. U niemowląt mocz zbierany jest do woreczka przyklejonego do skóry krocza, następnie, przelewa się go do czystego pojemnika. Woreczek powinien być odklejony zaraz po oddaniu moczu przez dziecko. Próbki moczu należy przekazać do badania w ciągu 1 godziny od pobrania. Mocz można przechowywać w lodówce maksymalnie do 4 godzin [11]. Badanie bakteriologiczne wykonuje się $\mathrm{w}$ celu rozpoznania zakażenia lub jego wykluczenia, weryfikacji czynnika etiologicznego i oznaczenia jego wrażliwości na leki przeciwbakteryjne [10]. Do pobrania moczu na badanie mikrobiologiczne metodą inną niż ze środkowego strumienia zaleca się cewnikowanie pęcherza moczowego. Pojemnik z moczem na posiew musi być jak najszybciej przetransportowany do laboratorium.

Wynik badań wskazały na wysoki poziom wiedzy badanych matek na temat zasad pobierania moczu do badania ogólnego. Wiedzą w tym zakresie wykazało się aż 92,1\% badanych. Niższym poziomem wiedzy wykazały się badane na temat zasad obowiązujących podczas pobierania moczu do badania bakteriologicznego (77,2\%). W badaniu nie stwierdzono statystycznie istotnych zależności pomiędzy częstością występowania ZUM u dzieci badanych matek, liczbą posiadanych dzieci a poziomem ich wiedzy na temat zasad obowiązujących podczas pobierania moczu do badań ( $p>0,05)$. Niezadawalający jest poziom wiedzy badanych na temat warunków w jakich powinien być przechowywany i transportowany mocz do laboratorium. Wiedzę na ten temat posiadało tylko 53,5\% ogółu badanych matek.

ZUM zbyt późno rozpoznane, nieleczone lub źle leczone, mające tendencję do nawrotów może być przyczyną wielu powikłań (np. zbliznowacenie nerek, PChN). Wiedza badanych w zakresie jest niezadawalająca. $64,4 \%$ badanych matek podało jako główne powikłanie nieleczonego ZUM nawracające ZUM, 45,5\% niewydolność nerek, 16,8\% uogólnione 
zakażenie krwi (urosepsę). Na zaburzenia rozwoju fizycznego dziecka wskazało $6 \%$ badanych. Brakiem wiedzy na temat możliwych powikłań ZUM wykazało się 13,9\% badanych matek. Zauważono związek między liczbą dzieci jakie posiadają badane, a częstością wskazań niewydolności nerek jako głównego powikłania nieleczonego ZUM $(\mathrm{p}<0,05)$.

Jedno $\mathrm{z}$ pytań zawartych $\mathrm{w}$ ankiecie dotyczyło zachowań badanych matek $\mathrm{w}$ przypadku wystąpienia u dziecka objawów mogących sugerować ZUM. Z przeprowadzonych analiz wynika, że zachowanie większości badanych jest prawidłowe. 84,2\% matek w przypadku wystąpienia pierwszych objawów sugerujących ZUM zgłasza się z dzieckiem jak najszybciej do lekarza, a 53,5\% badanych w pierwszej kolejności pobiera mocz do badania. $25,7 \%$ badanych matek po wystąpieniu u dziecka objawów sugerujących ZUM podaje dziecku lek odkażający drogi moczowe. Tylko 12,9\% badanych matek podaje dziecku większą ilość płynów do picia. 3,0\% ankietowanych leczy dziecko domowymi sposobami. Taki sam odsetek badanych wskazał na brak wiedzy jak należy postępować w przypadku wystąpienia u dziecka objawów wskazujących na ZUM.

Podstawą profilaktyki ZUM są wszelkie działania mające na celu zmniejszenie ekspozycji ujścia zewnętrznego cewki moczowej na zanieczyszczenia i eliminację uropatogenów i innych przyczyn mających znaczenie w etiopatogenezie ZUM u dzieci i młodzieży [3]. Priorytetem jest dbałość o higienę ogólną dziecka ze zwróceniem szczególnej uwagi na okolicę cewki moczowej i odbytu, leczenie stanów zapalnych okolicy cewki moczowej, regulacja wypróżnień. U wszystkich dzieci, nawet tych które nie miały ZUM i nie są $\mathrm{w}$ grupie zwiększonego ryzyka konieczne jest wyrobienie nawyku regularnych mikcji, nieprzetrzymywania moczu. Nie bez znaczenia jest dbałość o stan ogólny organizmu, poprawa stanu odporności dziecka, kształtowanie pożądanych nawyków żywieniowych i podaż dostatecznej ilości płynów do picia. W profilaktyce ZUM i ich nawrotów zaleca się niestosowanie do kąpieli i mycia okolic intymnych kosmetyków barwionych, zapachowych, pieniących się oraz unikanie korzystania z basenów, otwartych zbiorników wodnych, kąpieli W wannie [3]. Z punktu widzenia pielęgniarskiego ważna jest profilaktyka ZUM związanych $\mathrm{z}$ cewnikowaniem pęcherza moczowego (cewnikowanie tylko w sytuacjach koniecznych $\mathrm{z}$ zachowaniem zasad aseptyki i antyseptyki, zabezpieczenie przed cofaniem się moczu). Profilaktyka ZUM to nie tylko obowiązek personelu medycznego, ale także opiekunów dzieci i samych dzieci. Badanym matkom zadano pytanie na temat elementów ważnych w profilaktyce ZUM u dzieci. Wyniki badań nie są zadawalające. Tylko 53,5 \% badanych matek wskazało na dokładne mycie krocza ciepłą wodą i tylko 54,5\% na podmywanie dziewczynek zawsze od przodu do tyłu. Inne elementy profilaktyki wskazane przez badane matki, to: dokładne mycie pachwin, pośladków, moszny i prącia u chłopców $(41,6 \%)$, nieprzetrzymywanie moczu (43,6\%), leczenie chorób infekcyjnych (44,6\%), podawanie dziecku odpowiedniej ilości płynów do picia (41,6\%) i częsta zmiana pieluch $(36,6 \%) .25,7 \%$ ankietowanych matek wskazało na ubieranie dziecka stosownie do pory roku i warunków atmosferycznych, a $23,8 \%$ na częstą zmianę bielizny osobistej. Elementy mało istotne w profilaktyce ZUM, to: zwalczanie zaparć $(9,9 \%)$, leczenie owsicy $(8,9 \%)$, leczenie wad układu moczowego (8,9\%), profilaktyczne podawanie dziecku leków (5,9\%). Matki wychowujące 1 dziecko częściej wskazywały na: dokładne mycie krocza ciepłą wodą, a nie nasączonymi chusteczkami. Zauważono istotną statystycznie zależność pomiędzy częstością wskazań na konieczność zwalczania zaparć jako elementu profilaktyki ZUM, a częstością występowania u dzieci zakażeń w ciągu roku. Odpowiedzi takiej częściej udzielały matki, których dzieci miały 2-3 ZUM w ciągu roku $(\mathrm{p}<0,05)$.

Każda z matek maksymalnie mogła zdobyć 32 punkty. W tabeli zamieszczonej poniżej zawarto kryteria określające poziom wiedzy matek na temat ZUM u dzieci. 
Tabela III. Kryteria poziomu wiedzy badanych matek na temat ZUM u dzieci i ich profilaktyki.

\begin{tabular}{|c|c|c|}
\hline Ogólny Poziom Wiedzy & $\begin{array}{c}\text { Liczba punktów } \\
\text { zdobytych w teście } \\
\text { wiedzy }\end{array}$ & Odsetek poprawnych odpowiedzi \\
\hline Niski & $0-15$ & $0-49$ \\
\hline Średni & $16-21$ & $50-70$ \\
\hline Wysoki & $22-32$ & $71-100$ \\
\hline
\end{tabular}

Źródło: opracowanie własne.

Z przeprowadzonych analiz wynika, że większość badanych matek $(67,3 \%)$ posiadała niski poziom wiedzy na temat ZUM u dzieci i ich profilaktyki. Średni poziom wiedzy posiadało $23,8 \%$ badanych matek, a wysoki $8,9 \%$.

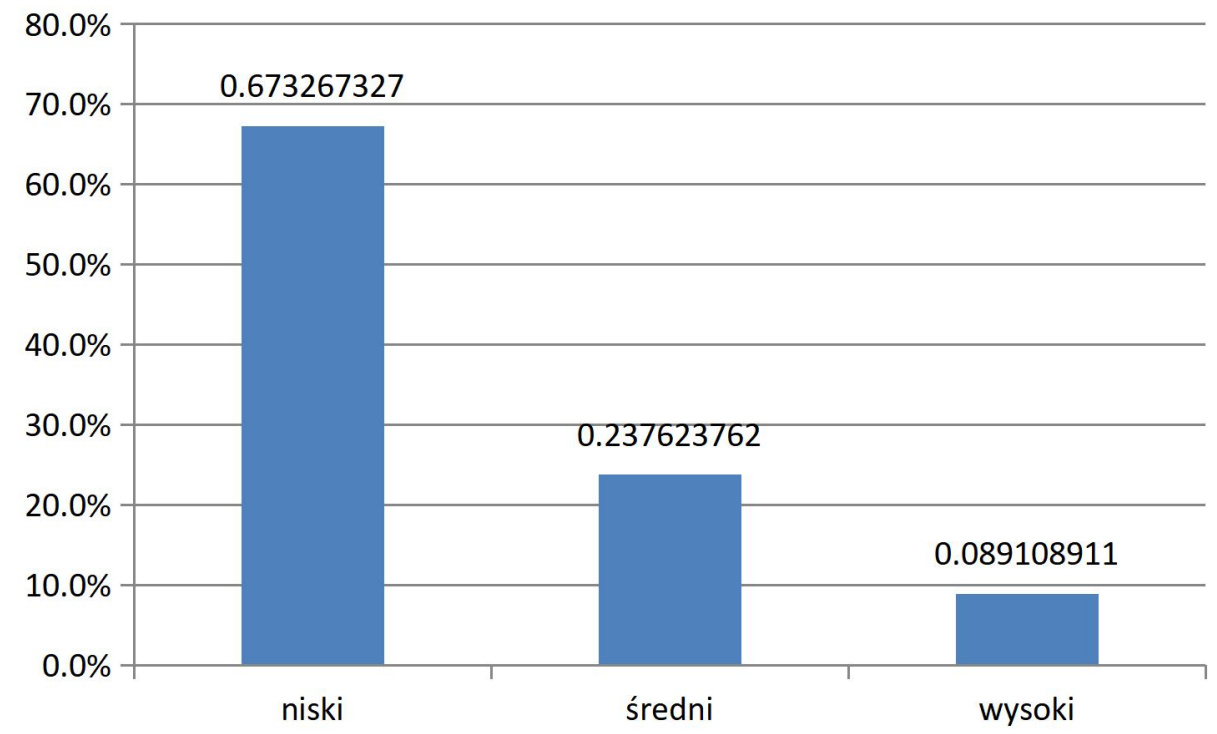

Wykres 1. Ogólny poziom wiedzy matek na temat ZUM u dzieci i ich profilaktyki Źródło: opracowanie własne.

Niskim poziomem wiedzy na temat ZUM wykazały się matki w wieku $\leq$, a wysokim matki w wieku $\geq 40$ lat. Wysokim poziomem wiedzy wykazało się tylko $15,1 \%$ mieszkanek miast powyżej 100 tys. mieszkańców. Niskim poziom wiedzy wykazało się 78,6\% mieszkanek wsi, $80 \%$ mieszkanek małych miast i 56,6\% matek zamieszkujących duże aglomeracje miejskie. Wysoką wiedzą na temat ZUM wykazały się matki z wykształceniem wyższym, pracujące w zawodach medycznych, deklarujące posiadanie bardzo dobrej sytuacji materialnej. Matki wychowujące dwoje dzieci opowiedziały poprawnie na więcej pytań aniżeli matki posiadające jedno lub więcej niż dwoje dzieci. Na najwięcej pytań w teście wiedzy poprawnie odpowiedziały też matki, u których dzieci ZUM występowało 2-3 razy w roku aniżeli matki, $\mathrm{u}$ których dzieci ZUM wystąpiło po raz pierwszy lub raz w roku. 
Tabela IV. Ilościowa analiza stanu wiedzy matek na podstawie odsetków poprawnych odpowiedzi w teście wiedzy.

\begin{tabular}{|c|c|c|c|c|c|c|}
\hline \multicolumn{2}{|c|}{ Odsetki poprawnych odpowiedzi } & $\mathbf{M}$ & $\mathrm{SD}$ & $\mathrm{Me}$ & $\min$. & maks. \\
\hline \multicolumn{2}{|l|}{ Razem } & 39,2 & 17,6 & 37,5 & 9,4 & 81,3 \\
\hline \multirow{3}{*}{ Wiek matki } & $\leq 30$ lat & 37,1 & 16,1 & 37,5 & 12,5 & 71,9 \\
\hline & 31-39 lat & 41,4 & 16,6 & 40,6 & 15,6 & 81,3 \\
\hline & $\geq 40$ lat & 37,6 & 21,0 & 31,3 & 9,4 & 78,1 \\
\hline \multirow{3}{*}{ Miejsce zamieszkania } & $\begin{array}{l}\text { miasto > } 100 \text { tys. } \\
\text { mieszkańców }\end{array}$ & 44,0 & 18,0 & 43,8 & 15,6 & 78,1 \\
\hline & $\begin{array}{l}\text { miasto do } 100 \text { tys. } \\
\text { mieszkańców }\end{array}$ & 37,5 & 14,5 & 31,3 & 18,8 & 81,3 \\
\hline & wieś & 31,4 & 16,2 & 25,0 & 9,4 & 65,6 \\
\hline \multirow{3}{*}{ Wykształcenie } & $\begin{array}{l}\text { podstawowe \& } \\
\text { zasadnicze }\end{array}$ & 27,3 & 16,5 & 21,9 & 9,4 & 56,3 \\
\hline & średnie & 38,5 & 15,8 & 37,5 & 12,5 & 78,1 \\
\hline & wyższe & 42,8 & 18,5 & 43,8 & 12,5 & 81,3 \\
\hline \multirow{3}{*}{ Wykonywany zawód } & medyczny & 43,0 & 21,1 & 43,8 & 12,5 & 78,1 \\
\hline & niemedyczny & 40,1 & 16,6 & 37,5 & 9,4 & 81,3 \\
\hline & nie pracująca & 31,4 & 14,4 & 29,7 & 9,4 & 53,1 \\
\hline \multirow{3}{*}{ Sytuacja materialna } & bardzo dobra & 52,2 & 20,1 & 53,1 & 21,9 & 78,1 \\
\hline & dobra & 38,8 & 15,7 & 40,6 & 9,4 & 81,3 \\
\hline & przeciętna & 33,1 & 17,3 & 29,7 & 9,4 & 75,0 \\
\hline \multirow{3}{*}{$\begin{array}{lll}\text { Liczba } & \text { dzieci } & \mathrm{W} \\
\text { rodzinie } & & \end{array}$} & jedno dziecko & 37,8 & 17,4 & 32,8 & 12,5 & 78,1 \\
\hline & dwoje dzieci & 41,1 & 18,0 & 40,6 & 9,4 & 81,3 \\
\hline & troje i czworo dzieci & 36,5 & 17,2 & 37,5 & 9,4 & 68,8 \\
\hline \multirow{3}{*}{$\begin{array}{l}\text { Częstość występowania } \\
\text { ZUM u dziecka }\end{array}$} & po raz pierwszy & 38,4 & 17,1 & 37,5 & 9,4 & 78,1 \\
\hline & raz w roku & 39,0 & 15,4 & 40,6 & 15,6 & 78,1 \\
\hline & 2-3 razy $w$ roku & 49,5 & 29,3 & 56,3 & 9,4 & 81,3 \\
\hline
\end{tabular}

*M-średnia, SD-odchylenie standardowe, Me-Mediana

Źródło: opracowanie własne.

Z przeprowadzonych badań wynika, że poziom wiedzy matek na temat ZUM u dzieci i ich profilaktyki był niski. Tylko $8,9 \%$ ankietowanych matek wykazało się wysokim poziomem wiedzy na temat ZUM, a $23,8 \%$ średnim. Wiek i miejsce zamieszkania matek nie wiązało się istotnie $\mathrm{z}$ ich poziomem wiedzy $(\mathrm{p}>0,05)$. Badane pracujące $\mathrm{w}$ zawodach nie związanych z medycyną miały wiedzę na poziomie średnim $(26,2 \%)$, a ankietowane nie pracujące na poziomie niskim $(83,3 \%)$. Wiedza osób $\mathrm{z}$ wykształceniem podstawowym i zawodowym była niska (81,8 \%). Badane matki deklarujące posiadanie bardzo dobrej sytuacji materialnej istotnie częściej niż pozostałe posiadały wysoki poziom wiedzy na temat ZUM u dzieci i ich profilaktyki $(\mathrm{p}<0,05)$. Liczba dzieci posiadanych przez badane matki nie pozostawała $\mathrm{w}$ związku z poziomem ich wiedzy na temat ZUM u dzieci i ich profilaktyki $(\mathrm{p}>0,05)$.

Badane matki zostały poproszone o samoocenę swojej wiedzy na temat ZUM u dzieci i ich profilaktyki. Najwięcej badanych oceniło swoją wiedzę w tym zakresie na poziomie dobrym $(44,6 \%)$ i dostatecznym $(43,6 \%)$. Na poziomie bardzo dobrym swoją wiedzę oceniło tylko $6,9 \%$ badanych matek. 5,0\% badanych matek wskazało na całkowity brak wiedzy na temat ZUM u dzieci i ich profilaktyki. Czynnikiem wpływającym na poziom wiedzy badanych na temat ZUM u dzieci i ich profilaktyki są źródła, z jakich badane czerpią informacje na ten temat. $Z$ przeprowadzonych badań wynika, że dla największego odsetka badanych źródłem wiedzy był lekarz $(67,3 \%)$ i Internet $(57,4 \%)$. W dalszej kolejności badane 
wskazały na: rodzinę i znajomych, na pielęgniarkę/ położną, czasopisma i fachową literaturę. Tylko 5\% badanych matek wskazało na telewizję jako źródło wiedzy na temat ZUM u dzieci i ich profilaktyki.

Analiza wyników badań była podstawą do sformułowania następujących wniosków:

1. Większość badanych matek $(67,3 \%)$ posiadała niski poziom wiedzy na temat ZUM

u dzieci i ich profilaktyki. Średni poziom wiedzy posiadało $23,8 \%$ badanych matek, a wysoki $8,9 \%$.

2. Niskim poziomem wiedzy na temat ZUM wykazały się matki w wieku $\leq 30$ lat, a wysokim matki w wieku $\geq 40$ lat. Wysokim poziomem wiedzy wykazało się 15,1\% mieszkanek miast powyżej 100 tys. mieszkańców. Niskim poziom wiedzy wykazało się 78,6\% mieszkanek wsi, 80\% mieszkanek małych miast i 56,6\% matek zamieszkujących duże aglomeracje miejskie. Wiek i miejsce zamieszkania matek nie wiązało się istotnie $\mathrm{z}$ ich poziomem wiedzy $(\mathrm{p}>0,05)$.

3. Wysoką wiedzą na temat ZUM wykazały się matki z wykształceniem wyższym. Wiedza osób z wykształceniem podstawowym i zawodowym była niska $(81,8 \%)$. Wykształcenie badanych matek nie wiązało się istotnie $\mathrm{z}$ ich poziomem wiedzy ( $\mathrm{p}>0,05)$.

5. Wysoką wiedzę miały matki pracujące $\mathrm{w}$ zawodach medycznych. Badane pracujące w zawodach nie związanych $\mathrm{z}$ medycyną miały wiedzę na poziomie średnim $(26,2 \%)$, a ankietowane nie pracujące na poziomie niskim (83,3\%). Różnice te nie były istotne statystycznie $(\mathrm{p}>0,05)$.

6. Badane matki deklarujące posiadanie bardzo dobrej sytuacji materialnej istotnie częściej niż pozostałe posiadały wysoki poziom wiedzy na temat ZUM u dzieci i ich profilaktyki. Różnice te nie były istotne statystycznie ( $p>0,05)$.

7. Matki wychowujące dwoje dzieci opowiedziały poprawnie na więcej pytań aniżeli matki posiadające jedno lub więcej niż dwoje dzieci. Liczba dzieci posiadanych przez badane matki nie pozostawała $\mathrm{w}$ związku z poziomem ich wiedzy na temat ZUM u dzieci i ich profilaktyki $(\mathrm{p}>0,05)$.

8. Na najwięcej pytań $\mathrm{w}$ teście wiedzy poprawnie odpowiedziały matki, u których dzieci ZUM występowało 2-3 razy w roku aniżeli matki, u których dzieci ZUM wystąpiło po raz pierwszy lub raz w roku. Różnice te nie były istotne statystyczne $(\mathrm{p}>0,05)$.

9. Najwięcej badanych oceniło swoją wiedzę na temat ZUM i ich profilaktyki na poziomie dobrym $(44,6 \%)$ i dostatecznym $(43,6 \%)$. Na poziomie bardzo dobrym swoją wiedzę oceniło tylko $6,9 \%$ badanych matek. 5,0 \% badanych matek wskazało na całkowity brak wiedzy na temat ZUM u dzieci i ich profilaktyki.

10. Dla największego odsetka badanych źródłem wiedzy na temat ZUM u dzieci i ich profilaktyki był lekarz (67,3\%) i Internet ( 57,4\%).

11. Przeprowadzone badania wskazują na konieczność edukacji społeczeństwa na temat ZUM i możliwości ich profilaktyki.

\section{Bibliografia}

1. Pawlaczyk B. (red.). Pielęgniarstwo pediatryczne. Podręcznik dla studiów medycznych. Wydawnictwo Lekarskie PZWL, Warszawa 2014.

2. Bochniewska V., Jung A., Żuber J. Zakażenia układu moczowego u dzieci. Pediatr Med. Rodz 2012;8(1):13-15.

3. Szalast A., Dudzic P. Pielęgnacja dziecka z zakażeniem układu moczowego. Nowa Pediatria 1/2012:13-16.

4. Grenda R., Ziółkowska H. (red.). Choroby układu moczowego. W: Kawalec W., Grenda R., Ziółkowska H. (red.). Pediatria. Tom I. Wydawnictwo Lekarskie PZWL, Warszawa 2013, ISBN 978-83-200-4630-4.

5. Duława J. Zakażenia układu moczowego. Medycyna Praktyczna, Kraków 1998.

6. Litwin M. Zakażenia układu moczowego u dzieci. Medical Tribune Polska, Warszawa 2012, 32-33. 
7. Sieniawska M., Kostro I. Zakażenia układu moczowego u dzieci.. Wydawnictwo Lekarskie PZWL, Warszawa 2000, Nowa Pediatria 1/2012,14-18.

8. Kiliś-Pstrrusińska K. Zakażenia układu moczowego u dzieci - co nowego 2012/2013?. Family Medicine \&Primary Care Review 2013;15,2:227-230.

9. Pączka L. (red.). Choroby wieku rozwojowego. Wydawnictwo Lekarskie PZWL, Warszawa 2006.

10. Kubicka K., Kawalec W. Pediatria. Podręcznik dla studentów. Wydawnictwo Lekarskie PZWL, Warszawa 2006.

11. Żurowska A. (red.). Zalecenia Polskiego Towarzystwa Nefrologii Dziecięcej (PTNFD) dotyczące postępowania $\mathrm{z}$ dzieckiem z zakażeniem układu moczowego. Forum Medycyny Rodzinnej 2016; tom 10,4:159-178.

12. Grenda R. Diagnostyka schorzeń nerek i układu moczowego u dzieci i młodzieży wybrane zagadnienia. Forum Nefrologiczne 2010; tom 3,1:51-56.

13. Litwin M., Niemirska A., Obrycki Ł. Standardy postępowania w zakażeniach układu moczowego u dzieci i młodzieży - rekomendacje IP-CZD. Standardy Medyczne/ Pediatria 2015; 1: 9-24.

14. Rakowska-Róziewicz D. (red). Wybrane standardy i procedury w pielęgniarstwie pediatrycznym. Wydawnictwo Czelej, Lublin 2001.

15. Duława J., Strzelczyk P. Zakażenia układu moczowego. Lekarz rodzinny 2004; 9:688692.

16. Beetz R. Zakażenie układu moczowego u dzieci. Pediatr. Nephrol.2006; 21:5.

17. Załęska-Ponganis J., Wolska M., Jackowska T. Zakażenia układu moczowego u dzieciwybrane aspekty postępowania na podstawie aktualnych zaleceń. Postępy Nauk Medycznych 6/2016, 429-435.

18. Nowakowska M., Rogala-Zawada D., Wiechuła B., Rudy M., Radosz-Komoniewska H., Zientara M. Czynniki etiologiczne zakażeń układu moczowego u dzieci i ich wrażliwość na antybiotyki. Wiadomości Lekarskie 2004;LVII:9-10. 